\title{
LITERARY REVIEW OF JANAPADODHWANSA WITH SPECIAL REFERENCE TO COVID - 19
}

\section{KEY WORDS:}

Janopadodhwamsa, Maraka, Janamaar, Hetuviprit, Vyadhivipritchikitsa.

\section{Selukar Rupali}

Yende Mohan*

\section{Thosar Sheetal}

\section{Gurmule Rajani}

Asso. Professor, Rognidan and Vikruti Vigyan, Bhausaheb Mulak Ayurved Mahavidyalaya, Nagpur.

Professor and Head, Rachana Sharir, Bhausaheb Mulak Ayurved College \& R. H.Butibori Di.Nagpur. *Corresponding Author

Professor and HOD, Dravyaguna, Shri K. R. Pandav Ayurveda College \& Hospital, Bahadura, Nagpur.

Asst. Professor, Rachana Sharir, Bhausaheb Mulak Ayurved College \& R. H. Butibori Di.Nagpur.

Ayurveda is an ancient system of medicine, clearly mentioned epidemic under a broad term 'Janapadodhwansa'. According to Ayurveda there are two types of Vyadhis based on causative factors which are stated in Charaka Samhita vimansthan chapter 3. Acharya Sushruta called it as Maraka and Acharya Bhela called it as Janamaar. There are four factors that has been described which are getting vitiated in Janopadodhwamsa. These are Vayu (air), Jala (water), Desha (land) and Kaala (season). Among these four factors Kaala is mainly main factor. Many of today's medical sciences coincide with some of the basic principles of Ayurveda. Today whole world is suffering from the COVID-19 pandemic. To assess the concepts of epidemiology in Ayurveda and to compare the same with recent COVID-19 pandemic, literary study of the epidemic was done thoroughly, including classical treatises like Charaka Samhita, Sushruta Samhita \& modern textbooks of epidemiology. Most of the concepts of Ayurveda about Janopadodhwamsa are found relevant to current theories of pandemic/epidemic. When COVID-19 pandemic compares with Janopadodhwamsa, it shows similarity in concepts like causative factors, modes of transmission, methods of prevention of outbreaks etc. Also, control measures of COVID-19 can be compared with Hetu-viparit \& Vyadhi-viparitchikitsa. The concepts described in Ayurveda regarding Janapadodhwansa are more or like the present modern concept of the pandemic or epidemic. Thus, the ancient Indian medicinal systems were well known to the fact of the epidemics \& outbreaks of infectious diseases.

\section{INTRODUCTION-}

The term Health in the modern science defines that it is the state of Physical, Mental , Spiritual and social well being and not merely the absence of disease. And Homeostasis means maintenance of constant internal environment of the body. ${ }^{(1)}$ As the change in external environment has its influence in the living organism, the importance of maintaining equilibrium with the nature is inevitable. Ayurveda, the science of life, deals the organism in a holistic way gives importance in maintaining health than the treatment of diseases. It gives more weightage to the prevention than the cure. ${ }^{(2)}$ Ayurveda is a perennial source of knowledge, known to mankind since several thousands of years, about cause, features and treatment of diseases, and ways to restore as well as promote health. Our ancient Acharyas explain Ritucharya which means methods for adapting with the changing environment which is not in our control. ${ }^{(3)}$ Ritu or season appear in nature due to the movement of sun, the prime energy source of the nature. As part of the movement of sun 6 Ritus manifest with diverse characteristics. Charya means the Anushtana or modifications which can make us in harmony with the environment. Acharyas explain modifications in every aspect of life such as Ahara, Viharas- bath, dress, sexual life, sleep etc. which help them to cope up with the environment thus help to lead a qualitative life. Natural calamities including epidemics and pandemic diseases are described in Ayurveda under the heading Janapadodhwansa. ${ }^{(4)}$ Diseases having similar signs and symptoms affecting many people of town, state and country at a time and can destroy the whole province is named as Janapadodhwansa. According to Charaka Samhita factors involved in Janapadodhwansa which in turn lead to vitiation of environmental factors are air, water, place and climate. War and other manmade calamities are also the causative factors for Janapadodhwansa. ${ }^{(5)}$ According to Chakrapani there are two kind of causes for diseases, Sadharana(typical) and Asadharana(atypical). Atypical is subjective cause that varies from human to human like Aahar(food), habits (Vihar) etc., which vitiates Dosha. Typical is common to many people. These typical treaties are Vayu (air), Jala (water), Desha (land) and Kaala (season). Diseases due to such common causes are called Janapadodhwansa. In
Charaka Samhita the causes for vitiation of such factors has also been described in a dedicated chapter focused on Janapadodhwansa. Among four factors Kala is considered as supreme among other three factors since Kaala Dushti may lead to vitiation of other three factors. Kala has direct relation with Ritu. ${ }^{(6)}$ If Ritucharya is followed properly we can tackle Kaala Dushti effectively.

Natural calamities including epidemics and pandemic diseases are described in Ayurveda under the heading Janapadodhwansa. Diseases having similar signs and symptoms affecting many people of town, state and country at a time and can destroy the whole province is named as Janapadodhwansa.

\section{Literary review-}

'Janpad' means group of people or community and 'Dhwamsa' means demolition indicating a condition of annihilation of people or community. ${ }^{(7)}$ Distinct terminology has been used for Janapadodhwansa by different Acharyas. AcharyaSushruta has termed this condition as Maraka (destroying condition) and emphasised the utilisation of Aushadh(herbs) and Jala(water) which are not affected or collected before the onset of Maraka.

Bhela has used the term Janamar for Janapadodhwansa and person has to use Mantras and Aushadh. Also he should remain busy in the greeting of bramhins. With this Janamar can be avoided. ${ }^{(8)}$

Affected Vayu [air] shows features such as it is excessive slow, excessive fast, annoying, extreme hot, too much dry, Excessive humid. This kind of Vayu causes vitiation of doshas in the body and causes disease in the person.

Affected Jala [water] shows features such as it has abnormal smell, colour, taste and touch also has sticky nature. The source of water like ponds, oceans has dried. The animals in the oceans died or gone somewhere else. The water which is tasteless is called affected. 
The geographical areas in which there is abnormal colour, smell, taste, and touch and there is excessive humidity in the air are said to be affected. Snakes, harmful animals, mosquitos, flies, mice, owls, eagles, foxes are more in those areas. Bushes are more in that area. Air is mixed with small dust particles, there is continuous chirping of birds and barking of dogs. Animals are running here and there. The people residing in that areas don't follow the proper way of living. They are not loyal. Also the oceans are roaring, the sun, moon are masked with orange, brown, or white clouds. Different types of noises are there in that geographical area.

When there is opposite, excess or less signs of seasons then it is called as abnormal Kala or season. ${ }^{(9)}$

One of the important reason for Janapadodhwansa has been described as Adharma and Adharma is a result of Pragyaparadha (delinquency of wisdom) ${ }^{(10)}$

\section{What Is COVID-19?}

Novel coronavirus to emerge in this century is called SARSCoV-2. It causes coronavirus disease 2019 (COVID-19), which emerged from China in December 2019 and was declared a global pandemic by the World Health Organization on March $11,2020{ }^{(11)}$ It is a kind of common virus that causes an infection in upper throat, nose, sinuses and also lower respiratory tract (windpipe and lungs). Most coronaviruses aren't dangerous. COVID-19 is a disease caused by SARS-CoV-2 that can trigger what doctors call a respiratory tract infection.

The main symptoms of Covid-19 are fever, coughing, shortness of breath, trouble breathing, fatigue, chills, sometimes with shaking, body aches, headache, sore throat, congestion/runny nose, loss of smell or taste, nausea, diarrhea. The virus can lead to pneumonia, respiratory failure, heart problems, liver problems, septic shock, and death. Many COVID-19 complications may be caused by a condition known as cytokine release syndrome or a cytokine storm. This is when an infection triggers immune system to flood bloodstream with inflammatory proteins called cytokines. They can kill tissue and damage organs. ${ }^{(12)}$ In some cases, lung transplants have been needed.

Some people who are hospitalized for COVID-19 have also have dangerous blood clots, including in their legs, lungs, and arteries. ${ }^{(13)}$ Unlike the flu, a lot of people aren't immune to the coronavirus because it's so new. If someone do catch it, the virus triggers body to make things called antibodies. Researchers are looking at whether the antibodies give the protection against catching it again.

The coronavirus also appears to cause higher rates of severe illness and death than the flu. But the symptoms themselves can vary widely from person to person.

While it had hoped intitially that higher temperatures and humidity levels might help slow the spread of the coronavirus, that was not the case. Experts advise caution and say thorough public health efforts have more influence than weather on the spread. Also, past flu pandemics have happened year-round.

Causes of the New Coronavirus- Researchers aren't sure what caused it and investigations as to its origin are ongoing. There's more than one type of coronavirus. They're common in people and in animals including bats, camels, cats, and cattle. SARS-CoV-2, the virus that causes COVID-19, is similar to MERS and SARS.They all came from bats. ${ }^{(14)}$

Coronavirus Risk Factors ${ }^{(15)}$ - Anyone can get COVID-19, and most infections are mild. The older the person is, the higher the risk of severe illness. The higher of illness are associated with chronic kidney disease, chronic obstructive pulmonary disease (COPD), a weakened immune system because of an organ transplant, obesity, serious heart conditions such as heart failure or coronary artery disease, sickle cell disease, type 2 diabetes, moderate to severe asthma, diseases that affect blood vessels and blood flow to brain, cystic fibrosis, high blood pressure, a weakened immune system because of a blood or bone marrow transplant, HIV, or medications like corticosteroids, dementia, liver disease, pregnancy, damaged or scarred lung tissue (pulmonary fibrosis), smoking, thalassemia, type 1 diabetes.

Some children and teens who are in the hospital with COVID19 have an inflammatory condition that doctors are calling multisystem inflammatory syndrome in children. Doctors think it may be linked to the virus. It causes symptoms similar to those of toxic shock and of Kawasaki disease, a condition that causes inflammation in kids' blood vessels.

Coronavirus Transmission $^{(16)}$ - SARS-CoV-2, the virus, mainly spreads from person to person. Most of the time, it spreads when a sick person coughs or sneezes. They can spray aerosol droplets 6 feet away or even further. Some people who have the virus don't have symptoms, but they can still spread the virus. While less likely, person can also get the virus from touching a surface or object the virus is on, then touching your mouth, nose, or possibly your eyes. Most viruses can live for several hours on a surface that they land on. That's why it's important to wash or sanitize hands regularly and disinfect surfaces to get rid of the virus.

\section{Coronavirus Prevention-}

- Getting vaccinated against COVID-19 is a key part of prevention. But should also take these steps:

- Cover nose and mouth in public.

- If someone have COVID-19, it can spread even if you don't feel sick.Wear a cloth face covering to protect others.

- Social distancing

- Washing hands often with soap and water or clean them with an alcohol-based sanitizer. This kills viruses on the hands.

- Don't touch face. Coronaviruses can live on surfaces you touch for several hours. If they get on the hands and touch your eyes, nose, or mouth, they can get into body.

- Practice social distancing.

- Clean and disinfect.

The CDC recommends that if one is not vaccinated, he should wear a cloth face mask if you go out in public. If you are at home with someone who has been infected or exposed, you should wear it as well. A mask is an added layer of protection for everyone, on top of social distancing efforts. You can spread the virus when you talk or cough, even if you don't know that you have it or if you aren't showing signs of infection. Crowded places can raise chances of getting COVID-19. The CDC recommends against international or cruise ship travel during the pandemic. Restrictions are being eased for those who are vaccinated, and some areas are using "vaccine passports" as a way to open up to vaccinated travelers.

\section{How to stop the spread of the coronavirus?}

Because the virus spreads from person to person, it's important to limit contact with other people as much as possible and avoid large gatherings. Many states and cities have eased restrictions but this doesn't mean the virus is gone. Continue to follow safety practices such as wearing a cloth face mask in public places and washing of hands. While many companies continue to use work-from-home practices, that is not possible for a lot of workers. Some people work in "essential businesses" that are vital to daily life, such as health care, law enforcement, and public utilities.

\section{DISCUSSION -}

As we have seen earlier in the literary review we can say that what todays Covid -19 pandemic is similar as Janapadodh wansa stated in Ancient texts. The four common factors i.e. Vayu, Jala, Desh, and Kala when gets vitiated causes diseases in the persons residing in the same areas. And Covid -19 is also spread from one person to another person by close 
contact or through sneezing or coughing of the person suffuring with Covid - 19 which is called as droplet infection. ${ }^{(17)}$ So when we correlate Covid -19 with Janapadodhwansa we can say that out of above four factors when Vayu and Desh gets affected it will cause covid -19 , because the corona virus can get transmitted from one person to another through droplets which are travelled through air when the person in direct contact with the infected person through his sneeze or cough. The virus can also stay on the surfaces and spread infection by touching those contaminated surfaces. So we can correlate it with the Desh or land. The foremost cause of Janapado dhwansa is Adharma and Pragyaparadha is responsible for Adharma. The definition of Dharma is "Dharanateeti Dharma", means the thing which we should follow properly either in the sense of self benefit or for the goodness of community. The things which are harmfull for nature should not be done by the human beings like industrialisation, cutting forest. It causes Air, Water pollution and ultimately leads to health hazards in all living beings. So human should avoid faulty practices causing air, land and water pollution thereby preventing the earth from deadly viruses like Covid 19. ${ }^{(18)}$

\section{CONCLUSION -}

Finally we can say that covid -19 is nothing but the Janapadodhwansa which is explained by our Acharyas before thousands of years back. The pandemic which we are facing today is caused by vitiation of mainly Vayu and Deshi. Air and Area or land. And the main cause for this Janapadoshwamsa is Adharma and for Adharma there is Pragyaparadh which is responsible for it.

\section{REFERENCES}

1. Callahan D. The WHO definition of'health'. Hastings Center Studies. 1973 Jan 1:77-87.

2. Kushwaha HC, editor.Pratham Bhag.Varanasi: Chowkhamba Orientalia;2009. Acharya Charaks' Charak Samhita.

3. Thakkar J, Chaudhari S, Sarkar PK. Ritucharya: Answer to the lifestyle disorders. Ayu. 2011 Oct;32(4):466.

4. Thakare SH,Jumade PP. Janapadodhwansa in Ayurveda \& its comparison with recent COVID-19 pandemic.Int.J.Res. Pharm. Sci..2020:297-303.

5. Jyotirmoy S, Rekha SD. Concept of epidemic diseases in ayurveda. IJHRMLP. 2016 Jan 1;2(01):24.

6. Ganeshrao BN, Somaji LD, Shrikrishna PA. Ritu (Season), Ritucharya and Prakriti-A Conceptual Study. Int.J Ayur.Pharma Research. 2014;2(2):101-10.

7. Kushwaha TK, Yadav S, Yadav Ashutosh AK. AN AYURVEDIC REVIEW ON JANAPADODHWANSA. wjpmr, 2021,7(5), 63-68..

8. Illustrated Bhela Samhita, (2017) translated by Shri AbhayKatyayana, Published by ChaukhambhaSurbharti Publication, Sutrasthana Chapter 13 Sloka no.9, page no. 76

9. Tiwari PV, Charak Samhita. [English Translation of Text with Ayurveda Dipika commentary of Chakrapanidatta] Edition Chaukhambha Vishvabharati, Varanasi.2018; 1(151):7-8.

10. Illustrated Charaka Samhita, (2015) translated by Pt. KashinathShastri and Dr. GorakhnathaChaturvedi, Published by Chaukhambha Bharti Academy, Sutra Sthana Chapter 11 Sloka no. 43,Page No. 233.

11. Cucinotta D, Vanelli M. WHO declares COVID-19 a pandemic. Acta Bio Medica:Atenei Parmensis. 2020;91(1):157.

12. Ragab D, Salah Eldin H, Taeimah M, Khattab R, Salem R. The COVID-19 cytokine storm; what we know so far. Frontiers in immunology. 2020 Jun 16;11:1446.

13. Helms J, Tacquard C, Severac F, Leonard-Lorant I, Ohana M, Delabranche X, Merdji H, Clere-Jehl R, Schenck M, Gandet FF, Fafi-Kremer S. High risk of thrombosis in patients with severe SARS-CoV-2 infection: a multicenter prospective cohort study. Intensive care medicine. $2020 \mathrm{Jun}$;46(6):1089-98.

14. Watanabe S, Masangkay JS, Nagata N, Morikawa S, Mizutani T, Fukushi S, Alviola P, Omatsu T, Ueda N, Tha $\mathrm{K}$, Taniguchi S. Bat coronaviruses and experimental infection of bats, the Philippines. Emerging infectious diseases.2010 Aug;16(8):1217.

15. Chen R, LiangW,Jiang M, Guan W, Zhan C,Wang T, Tang C, Sang L, Liu J, Ni Z, Hu Y. Risk factors of fatal outcome in hospitalized subjects with coronavirus disease 2019 from a nationwide analysis in China. Chest. 2020 Jul 1;158(1):97105.

16. World Health Organization. Transmission of SARS-CoV-2: implications for infection prevention precautions: scientific brief, 09 July 2020. World Health Organization; 2020

17. Liu, J., Liao, X., Qian, S., Yuan, J., Wang, F., Liu, Y., Wang, Z., Wang, F. S., Liu, L., Zhang, Z. 2020. Community Transmission of Severe Acute Respiratory Syndrome Coronavirus 2. Emerging infectious diseases, (6):26-26.

18. Shukla, R., Dwivedi, O., Jain, J., Khuje, S. 2019. ROLE OF RASAYAN IN COMMUNICABLE DISEASE (Janapadodhwansa). EUROPEAN JOURNAL OF PHARMACEUTICAL AND MEDICAL RESEARCH, 6(1):232-234. 